\title{
STAFF MOTIVATION AND EMPLOYEE PERFORMANCE: A STUDY OF BAYELSA STATE POLYTECHNIC ALEIBIRI, BAYELSA STATE, NIGERIA
}

\author{
${ }^{1}$ Ogbomah, Oyin-Emi Frank \\ Department of Public Administration, Bayelsa State Polytechnic, Aleibiri. \\ ${ }^{2}$ Okoko Sinizibe \\ Department of Public Administration, Bayelsa State Polytechnic, Aleibiri.
}

${ }^{3}$ Kakatei Juanita

Department of Business Administration and Management, Bayelsa State Polytechnic, Aleibiri.

\begin{abstract}
Human resource is the heart of every organization because every other resources depend on the human resources for effective utilization. For the human resource to perform its activities effectively, there must be some level of motivation given to the workers. This paper examines motivation as a way of improving workers' performance in Bayelsa State Polytechnic, Aleibiri. In this work, the meaning of motivation was conceptualized, its impacts on workers' performance, factors that motivate workers, causes of poor workers performance among others are extensively discussed. To achieve the objective of the paper, primary and secondary data were used. The survey research design method was used to obtain the primary data. That is, questionnaire was designed and administered to the respondents. The simple random sampling technique was adopted to ensure that every member of the population is giving equal chance to be included for the study. Data collected from the field was analyzed witharithmetic. The secondary source of data includes textbooks and journal articles. The result from the findings revealed that non-implementation of staff promotion, inadequate staff training, unconducive working environment among others contribute to low workers' performance. Furthermore, the study also revealed that, implementation of staff promotion, study leave with full pay, payment of promotion arrears, staff training motivate and enhance worker performance.Arising from the findings, the study recommend that government should implement staff promotion and as well pay all outstanding promotion arrears to workers. Also, staff should be granted study leave with full pay and regular staff training programme should be organized to help workers acquire new skills to enhance their job performance.
\end{abstract}

Keywords: Motivation, Employee, Performance, Organization. 


\section{INTRODUCTION}

The human resource is the most complex of all the factors of production. This is because it is the human resource that putsother factors of production into use, therefore any organization policy that does not lay emphasis on the human factor is not likely to produce any desired result from the workers. Onah (2015:290) posit that people work for a wide variety of reasons. He argued that some want money, some want challenge and others need security in the job. The things that each want from the organization plays an important role in determining their motivation to work.

Motivation is an important ingredient in achieving workers' performance and actualizing organizational goals. Motivation is the drive which propels workers to put in more effort in their daily activities. The performance of the workforce and the productivity of the organization to a large extent depend on the level of motivation given to the workers.

When workers are motivated, their job performance increases which in the long run contribute to the overall productivity of the organization. In other words, there is a close relationship between motivation and the work done by the workers and organizational productivity. The greater the motivation, the higher the productivity and job satisfaction. The lower the motivation the lower productivity and morale (Sharma, Sadanna\& Harpreet, 2013:750).

Motivation requires the use of financial incentives but in some cases non-financial incentives are used. Organizations should ensure that they pursue policies that will effectively motivate workers to bring out the best in them for the purpose of achieving the goals of the organization.

\section{STATEMENT OF THE PROBLEM}

Organizations are established to achieve goals. These goals could be long or short term depending on the nature of the organization. In achieving these goals most organizations come across a lot of problems. One of such problems is the issue of workers performance. The problem of workers performance and productivity is a major challenge facing organizations. Workers join organization to satisfy their needs and when these needs are not met by the organization due to poor wage, bonuses and some other incentives and conditions of work, dissatisfaction sets in which affects their performance.

According to Onitiri(1983) cited in Alamieyeseigha (2002: 115), low staff productivity is an aspect of the vicious cycle of poverty in which many developing nations are trapped. He added that poor standard of living - bad health, lack of education, bad housing, poor transportation, bad conditions in the work place etc, reduced the workers' productivity and low productivity in turn reduces the capacity of the society to improve living standards. In a similar vein that Duku (1984: 22) aptly stated that the average Nigerian worker is motivated to work because of the monetary reward that accompanies work. The resultant effect is that when such rewards are not forth coming it affects the job performance of the workforce.

Organizations must motivate their workers through improved wage, bonuses, conditions of work etc. The problem therefore is how to identify the factors that cause poor workers performance and motivate workers in order to enhance their job performance. 


\section{RESEARCH QUESTIONS}

The following research questions will guide the study.

(i) What are the causes of poor workers performance in your institution?

(ii) What strategy should your management adopt to motivate workers in your institution?

(iii) What are the benefits of staff motivation?

\section{OBJECTIVE OF THE STUDY}

The broad objective of this paper is to examine staff motivation and its impact on workers' performance. The specific objectives are to:

(i) Identify factors that causepoor workers' performance in an organization.

(ii) Identify various strategies that can be adopted to motivate workers.

(iii) Examine the benefits of staff motivation.

(iv) Suggest measures to improve workers performance.

\section{CONCEPTUAL REVIEW/THEORETICAL FRAMEWORK}

\section{MOTIVATION}

Motivation has been defined in different contexts depending on the standpoint of the person defining it, thus bringing to conclusion that there is no universally accepted definition of the concept.

The word motivation is derived from the Latin word "movere" meaning to move (Sharma, Sadana \& Harpreet, 2013:750). It is like a force because it makes workers put in more effort into their daily activities. It has to do with human instincts, aspirations and urges that direct and control human behaviour. According to Yahaya \& Akinyele (1992:154), motivation can be viewed as whatever it takes in encouraging workers to perform by fulfilling or appealing to their needs. It is directed toward a goal and therefore cannot be outside the goals of any organization whether public or private or non-profit organization.

Robbins (1993) cited by Falsal, Husam, Faiz\&Dia (2017:135) defines motivation as "the willingness to exert high level of effort toward organizational goals, conditioned by the efforts ability to satisfy some individual need". The above means that the essence of motivating workers is to achieve organizational goals and individual needs.Motivation is some driving force within individuals by which they attempt to achieve some goal in order to fulfill some need or expectation. Mullins posits that these needs and expectations can be categorized into physiological and social motives or intrinsic and extrinsic motivations (Sharma, Sadana \& Harpreet, 2013:751).

Extrinsic motivation according to Sharma, Sadana \& Harpreet (2013:751), is related to tangible rewards such as salary, fringe benefits, promotion etc. Mohsan, Nawaz, Khan, Shaukat, \& Aslam 
(2004:226) posit that employees who are externally motivated, generally don't enjoy the tasks but are motivated to perform well by some reward, such as pay, promotion etc. Intrinsic motivation on the other hand is related to physiological rewards such as opportunity to use one's ability, a sense of achievement, receiving appreciation, positive recognition etc,(Sharma, Sadana \& Harpreet,2013: 751).

A more elaborate definition of motivation was given by Nwanchukwu (1988:198). He defined motivation as the energizing force that induces or compels and maintains behaviour. According to him, motivation could be seen as an instrument of inducement aimed at increasing employee morale and efficiency in order to propel optimum output. Nwanchukwu went further to identify three basic characteristics of motivation and they are:

(i) It is sustained: It means that a motivated worker does not get satisfied at once. It is maintained for a long time before satisfaction sets in.

(ii) It is goal oriented: He posited that the aim of motivating a worker is to achieve a specific goal.

(iii) It results from a felt need: It is an urge directed toward a need. It may be profit or reputation.

In the opinion of Alamieyeseigha (2002:319), motivation is what makes an individual act in a particular way. It is an inner state that moves an individual into action that enables him to achieve goals or satisfy needs. He stated that management should know that it is not the physique of the worker that is important, it is not his capacity to work that is important but his will power. Alamieyeseigha added that if a worker is not willing to make use of his ability it will be difficult to achieve the productivity goal of an organization. The management should therefore be able to know what motivates a worker to put in his best.

In a similar vein, Onah (2015: 290) states that motivation represents the forces within a person that affect his or her direction, intensity and persistence of voluntary behavior. According to Pinder (1984) cited in Onah (2015: 291), direction refers to the fact that motivation is goal oriented, not random. Intensity is the amount of effort allocated to the goal. For example, too many employees might be motivated to finish their jobs a few hours early (direction), but only one of them put forth enough effort (intensity) to achieve the goal.

Arising from the above definitions, it is clear that motivation is the drive that propels workers to put in their best in the organization. Motivation requires the use of financial incentives but in some case non-financial incentives are used. It is important to mention here that there is no straightjacket way to motivate a worker. An approach adopted to motivate one individual may not work for another individual in the same organization. There are motivations which are short term and others long term. For example, the goal of a hungry man is to satisfy his hunger need. Once he eats food the hunger need is satisfied and it is no longer a motivational force. There are some other needs that do not lose their potency after satisfaction but persists and even increase in strength with time. The need for recognition may not reduce or die when some satisfaction has been achieved. It may be a reason for a higher desire. Needs rarely exist in isolation. Several different needs can operate side by side or simultaneously and some are in conflict with others. 


\section{EMPLOYEE PERFORMANCE}

Employee performance is one of the major topic in organizational discourse. This is because employee performance is among the critical factors that contributes to the success of any organization

According to Zuheir (2018:12), employee performance is the accumulated result of skills, efforts and abilities of all the employees contributed in organizational improved productivity leading towards its goal achievement. In a similar vein, Shora \& Khurrams (2011:5250) stated that employee performance represents the general belief of employee about his behaviour and contributions in the success of organization. They added that employee performance may be taken in the perspective of three factors which make it possible for employees to perform better than others. The determinants of performance may be such as declarative knowledge, procedural knowledge and motivation.

Employee performance from the above definitions means the ability of employees to effectively discharge their responsibilities for the achievement of the organizational goals at minimum cost. In other words, employee performance has to do with the overall contributions of the workers towards achieving the set goals of the organization without incurring much cost for the organization. It should be pointed out that employee performance is related to the commitment the management or the organization exhibit towards the workers. The importance of employee performance must be understood by management and sincere effort must be put in this direction. Hence, to bring out the maximum best from the worker, organizations must meet the needs of their workforce.

\section{FACTORS THAT CAUSE POOR EMPLOYEE PERFORMANCE}

There are a lot of factors that contribute to poor workers performance particularly in Nigeria. Among such factors are:

(i) Poor Wage: The wage of the Nigerian worker is very poor compared to the level of inflation in the country. The high rate of inflation that follows every salary increase rubbishes the workers' purchasing power. The net effect of all this is that workers have difficulty in meeting their needs and become social outcaste because they dodge social gatherings where money talks in order to avoid disgrace. Those who attend hide their face in shame when naira rains. Furthermore, the periodic hike in the pump price of Premium Motor Spirit (PMS) makes nonsense of workers' pay package (Alamieyeseigha, 2002: 134).

(ii) Poor Leadership: This is another problem facing workers performance in most organizations. A leader that does not have the will power to control and inspire the workers will lead to poor workers performance. Effective leadership makes an affective workforce. Workers are more satisfied when their managers are good leaders. Good leadership requires motivating the workers to become efficient and productive. When the leader is weak, the workers see their job as no man job. The resultant effect of such attitude from the workers is poor performance. 
(iii) Lack of Skills: Sometimes staff performance problem is simply associated with lack of skills. Lack of skill results from inadequate staff training programme for the workforce. It is on this ground that Abubakar (1992) cited in Mukoro (2007:7) pointed out that human resource training is a sine qua non for the attainment of efficiency and effectiveness which are the two major goals/objectives of a good Civil Service. Training helps workers to acquire the needed skills and knowledge to discharge their duties.

(iv) Unconducive Work Environment: The work environment is a major determinant for workers performance. Workers are concerned with their work environment for both personal comfort which also facilitates their job performance. Studies demonstrate that employees prefer physical surroundings that are not dangerous or uncomfortable. When the work environment is not conducive, complaints set in which affect workers' performance.

(v) Lack of Motivation: Motivation is the pinnacle for employee performance. Workers motivation comes in different ways. It can be financial incentives and non-financial rewards. Personal recognition and sincere appreciation like thank you for a job well done is powerful tool in motivating workers. Workers may begin to avoid their work if they perceive that their hard work goes unnoticed. For example, dissatisfaction sets in when people realize that no recognition is given to them despite their effort in moving the organization forward.

\section{STRATEGIESTO IMPROVE WORKERS PERFORMANCE}

Alamieyeseigha (2002:323) posit that money, that is, good pay can bring people to the doorstep of your organization seeking entry but when eventually you allow them in, money alone cannot keep them from walking out the door. This means that factors that motivate workers in an organizations differs among individuals. He added that when people say 'I love my job', a lot is hidden behind the statement. Does one love his job because he is paid a fantastic salary? Is it because he is provided a house and car? Is it as a result of the environment and the people he works with or is it as a result of his boss?

According to Alamieyeseigha (2002:327), the following strategies if adopted will motivate workers and improve their job performance.

(i) Good Leadership: Effective leadership makes an effective workforce. Workers are more satisfied when their managers are good leaders. Good leadership entails motivating workers to strive for excellence in job performance and become productive. Good leadership demands that managers must be well trained in attitudes and behaviour. They should be able to build trust and inspire workers to achieve meaningful goals.

(ii) Adequate Authority: There is no worker that loves his boss breathing down his neck in the workplace, neither does he want to work like a robot. Workers are more satisfied when they have adequate freedom and authority to do their jobs. Workers should be allowed to make inputs in the establishment of goals and how they will accomplish them. 
(iii) Challenging Work and Opportunity: Challenging opportunities breed satisfaction. Workers look for challenges in the course of their job. They like to move on the higher challenges as they finish one assignment. They want a chance to participate in interesting projects, jobs that boast of a satisfying degree of challenge and opportunity for increased responsibility. Where there are no challenges, workers laze about physically and mentally. In the Civil Service of Nigeria, many people go to work daily without having a new task to tackle, no challenges. They are left with the same old routine tasks that become boring with time. It should however be noted that challenging opportunities are not limited only to promotional opportunity. People find challenges through projects, team leadership, special assignments, as well as promotions.

(iv) Equitable Rewards: Workers want reward that is commensurate with their input. Nigerian workers over the years have been at daggers drawn with the Federal government over payment of what they consider as 'Living Wage' to Nigeria workers. They feel cheated because workers' salaries under normal circumstances are poor when compared to the rate of inflation (Alamieyeseigha, 2002:328). Those in the private sector move from one organization to the other not in search of any other thing than better salary. Employees are more satisfied when they feel they are rewarded fairly for the work they do. When rewards are seen as fair based on job demands, individual skill level, and competitiveness, satisfaction is likely to result. Similarly, workers who perceive that promotion decisions are made in a fair and just manner are most likely to experience satisfaction from their jobs.

(v) Provide a Positive Working Environment: This is what turns people on, that motivates them. Providing a positive work environment is the beginning of motivation. It simply means going the extra mile, even beyond the call of duty to cater for the needs of the worker. Happy employees make productive employees. How the employees feel about the organization matters a lot and, it has a significant impact on employee attitudes. When employee attitude improves, customer satisfaction also improves. Seeking ways to motivate and build morale of the workers is of immense benefit to any organization as it yields dividends. The motivated workers are more committed to his job and to the customer. Organizations should realize the importance of taking care of their employees' needs to keep them motivated on the job and loyal to them.

(vi) Recognize Everyone's Efforts: Personal recognition and sincere appreciation are powerful tools in keeping good workers. It helps in building morale and motivation. Little things like personal thank you notes from peers, a pat on the back, a sincere handshake from a peer or supervisor does wonders. In the organization, recognition can originate from one's peer, superior, informal and formal events or celebrations. In building a motivation reward and recognition system, some fun can be added. The importance of fun in the workplace is the breaking of monotony of the job. People can take a trip once a year to special and exotic celebrations or festivals etc. These events build teamwork and can make a difference.

(vii) Involve Everyone: When workers are involved at all levels of the organization, it gives them a true sense of belonging and pride. It motivates them and thereby makes them more productive. Teams and teamwork are good avenues of involving the worker. Teams 
by their essence and nature improve productivity, increase morale and empower workers. Working together as a team is a great motivational tool that makes employees happy on the job.

(viii) Develop Workers' Skill and Potential: Training and development motivatepeople and make them more productive and innovative. When workers are well- trained, they are more capable and ready to assume greater responsibility as well as exercise more control over their jobs. The workers are also capable of performing their job without much supervision from their superior as a result of the training they have acquired.

\section{MOTIVATION AND EMPLOYEE PERFORMANCE}

The following are the impacts of motivation on staff performance and organizational productivity according to (Ojo and Sokoh, 2015:156).

(i) Interest in the Work: Motivated workers are very much interested in their job, happy and dedicated to the service of the employer or organization. When workers are motivated, they see the work as their own work and are always interested in the work. There is no dull moment in the job because workers find pleasure doing their assigned duties. The implication is that it increases the productivity of the organization.

(ii) Punctuality and Regularity to Work: As a result of their interest, commitment and dedication, workers are always punctual to work as they want to achieve the set target of the organization. The rate of workers absenteeism is low, also workers will not deliberately absent themselves from work because they find their job as a source of joy and will not like to miss their work and colleagues in the office.

(iii) Loyalty to the Organization: Motivated employees are loyalists to the core and associate themselves with the achievement of the organization even after they exit the organization. It is very difficult for a motivated worker to sabotage the effort of the organization. They want to see the organization grow and fulfill the goals of the organization.

(iv) Production Target: Various production targets set by the organization will be met even surpassed where the workers are adequately motivated. The workers know that the more production target they meet the more they will be appreciated in the organization.

(v) Obedience to Rules and Regulations: Motivated workers are always obedient to the rules and regulations governing them as well as the organization. Because the workers are motivated, they are always ready to obey the rules and regulations of the organization. Hardly will workers go against the set down rules and regulations governing them. As a result of workers obedience, hiring and firing of staff is rear and the cost of recruiting new employees to the organization is very minimal.

\section{THEORETICAL FRAMEWORK}

This paper is anchored on ExpectancyTheory of Motivation propounded by Victor H. Vroom in 1964. Vroom believes that motivation depends on two things:

(i) How much we value something,

(ii) The likelihood that our action will lead us into getting that thing we really value. 
Victor Vroom sees motivation as the process that governs the selection pattern of employees when faced with a set of alternatives, first-level outcome. He holds that people will be motivated to do things to reach a goal if they believe in the worth of the goal and if they see that what they do will help them in achieving it. In greater detail, Vroom's theory posits that workers motivation toward doing anything will be determined by the value they placed on the outcome of their effort (whether positive or negative), multiplied by the confidence they have that their efforts will materially aid in achieving a goal. The theory is based on three factors: Expectancy, Valence and Instrumentality.

\section{Expectancy}

This is the individual's belief that his effort will bring about a desired result of first-orderoutcome. If the belief is strong, then expectancy is quite strong. In a situation where the individual believes that effort cannot lead to desired results or that effort and performance are unrelated, expectancy is weak. In some cases, the individual may believe that effort is somehow but not strongly related to performance in which case he believes that efforts may or may not lead to desired result, expectancy is moderate.

\section{Valence}

This is the value of the expected outcome to the individual. It is an index of the desirability of rewards of the effort to the individual. If the individual seriously desire the outcome, its valence is positive. If he does not desire the outcome its valence is negative and if he is indifferent to the outcome its valence is zero.

\section{Instrumentality}

This refers to an individual's belief that the attainment of first level outcome will lead to a second level outcome. The first-level outcome may be successful completion of the assigned task (organizational objective) while the second level outcome may be gaining promotion or pay raise (personal objective). Instrumentality therefore is the likelihood that achieving the organizational objective will help in the realization of individual personal objective or goal. It is the measure of relationship between performance and reward.

Based on three factors explained above, one can say that motivation depends on the probability that an action will lead to desired outcome Expectancyand that the value of that outcome is desirable to the individual Valence, and that the achievement of the first-level outcome or performance will lead to the attainment of second-level outcome Instrumentality (Obiajulu and Obi, 2004).

The significance of Vroom's theory is that an individual desires his assessment and predictions of what the authority of the organization is likely to behave may determine the worker motivational rate and performance.

\section{METHOD OF THE STUDY}

Survey design was employed in this study to elicit information from staff of Bayelsa State Polytechnic Aleibiri on staff motivation and workers performance. The primary source of data 
was collected through questionnaire and interview while the secondary source includes textbooks and journal articles.

The population of study is 269 staff of the Polytechnic. The sample size of 50 was derived using simple random sampling technique. Well-structured questionnaire developed by the researcher was used as instrument for data collection. Fifty questionnaire were distributed out of which 43 were retrieved. Also, personal interview was conducted with some staff of the Polytechnic to corroborate the data collected from the questionnaire.

The arithmetic mean is used to analyze the data collected from the respondents.

\section{ANALYSIS OF RESEARCH QUESTIONS}

Research question one (1) what are the cause of poor workers performance in Bayelsa State Polytechnic Aleibiri?

Table 2.1 Breakdown of response from Item 1 - 4

\begin{tabular}{|c|c|c|c|c|c|c|c|}
\hline $\mathbf{S} / \mathbf{N}$ & ITEM STATEMENT & $\begin{array}{l}\text { SA } \\
(4)\end{array}$ & $\begin{array}{c}\mathbf{A} \\
\mathbf{( 3 )}\end{array}$ & $\begin{array}{l}\text { SD } \\
\text { (2) }\end{array}$ & $\begin{array}{c}\text { D } \\
(1)\end{array}$ & TOTAL & $\mathbf{X W}$ \\
\hline 1 & $\begin{array}{l}\text { Non-implementation of staff promotion causes } \\
\text { low staff performance. } \\
\text { Weight of response }\end{array}$ & $(84)$ & $(48)$ & $(8)$ & $(2)$ & 142 & 3.3 \\
\hline 2 & $\begin{array}{l}\text { Non-payment of promotion arrears causes } \\
\text { poor staff performance. } \\
\text { Weight of response }\end{array}$ & 23 & $(45)$ & (6) & (2) & 145 & 3.3 \\
\hline 3 & $\begin{array}{l}\text { Inadequate staff training leads to low } \\
\text { performance. } \\
\text { Weight of response }\end{array}$ & $\begin{array}{l}19 \\
(76)\end{array}$ & $\begin{array}{l}18 \\
(54)\end{array}$ & (6) & (3) & 43 & 3.2 \\
\hline 4 & $\begin{array}{l}\text { Unconducive work environment causes poor } \\
\text { staff performance } \\
\text { Weight of response }\end{array}$ & $\begin{array}{r}20 \\
(80) \\
\end{array}$ & (54) & $(4)$ & $(3)$ & 141 & 3.2 \\
\hline
\end{tabular}

\section{Source: Field Survey 2020}

$\mathrm{TW}=$ Total Weight

$\mathrm{XW}=$ Mean of Weighted Scores.

Figures in Bracket $(\quad)$ are weighted scores

$$
\begin{aligned}
& \text { Criterion Mean }=\frac{S A(4)+A(3)+D(2)+S D(1)}{4} \\
& =\frac{4+3+2+1}{4}=\frac{10}{4}=2.5
\end{aligned}
$$




$$
\begin{aligned}
& \text { Weighted Mean }=\frac{\Sigma X W}{N} \\
& =\frac{3.3+3.7+3.1+3.3}{4}=\frac{13}{4}=3.2
\end{aligned}
$$

\section{DECISION RULE}

We accept if mean of weighted mean is greater than (>) criterion mean and reject if criterion mean is greater than $(>)$ mean of weighted means. Criterion mean $(\mathrm{x})=2.5$, Mean $(\mathrm{x})$ of weighted means $=3.1$

Since the mean $\mathrm{x}$ of the weighted mean 3.1 is greater than (>) the criterion mean 2.5 , the response from the respondents is positive. That is, the items statements above in table 2.1 are the causes of poor workers performance in Bayelsa State Polytechnic Aleibiri.

Research question two (2) what strategy should your management adopt to motivate workers in your institution?

\begin{tabular}{|c|c|c|c|c|c|c|c|}
\hline $\mathbf{S} / \mathbf{N}$ & ITEM STATEMENT & $\begin{array}{l}\text { SA } \\
\text { (4) }\end{array}$ & $\begin{array}{l}\text { A } \\
\text { (3) }\end{array}$ & $\begin{array}{l}\text { SD } \\
\text { (2) }\end{array}$ & $\begin{array}{l}\text { D } \\
\text { (1) }\end{array}$ & TOTAL & $\mathbf{X W}$ \\
\hline 5 & $\begin{array}{l}\text { Promotion implementation will motivate and } \\
\text { enhance workers performance. } \\
\text { Weight of response }\end{array}$ & 22 & $\begin{array}{l}17 \\
(51) \\
\end{array}$ & (4) & (2) & 43 & 3.2 \\
\hline 6 & $\begin{array}{l}\text { Study leave with full pay will motivate workers } \\
\text { Weight of response }\end{array}$ & $\begin{array}{l}17 \\
(68)\end{array}$ & $\begin{array}{l}19 \\
(57) \\
\end{array}$ & (8) & (3) & 43 & 3.1 \\
\hline 7 & $\begin{array}{l}\text { Regular staff training programme will enhance } \\
\text { workers performance } \\
\text { Weight of response }\end{array}$ & $\begin{array}{l}18 \\
(72)\end{array}$ & (54) & (6) & (4) & 43 & 3.1 \\
\hline 8 & $\begin{array}{l}\text { Provision of conducive work environment will } \\
\text { motivate and enhance workers performance. } \\
\text { Weight of response }\end{array}$ & $\begin{array}{l}19 \\
(76)\end{array}$ & \begin{tabular}{l|}
19 \\
$(57)$ \\
\end{tabular} & (4) & (3) & $\begin{array}{l}43 \\
140 \\
\end{array}$ & 3.2 \\
\hline
\end{tabular}

Table 2.2 Breakdown of response from Item $5-8$

\section{Source: Field Survey 2020}

\section{DECISION RULE}

We accept if mean of weighted mean is greater than (>) criterion mean and reject if criterion mean is greater than $(>)$ mean of weighted means. Criterion mean $(\mathrm{x})=2.5$, Mean $(\mathrm{x})$ of weighted means $=3.1$

Since the mean $x$ of the weighted mean 3.1 is greater than (>) the criterion mean 2.5 , the response from the respondents is positive. In other words, the items statements above in table 2.2 
are the strategies management should adopt to motivate workers in Bayelsa State Polytechnic Aleibiri

Research question three (3) what are the benefits of staff motivation?

Table 2.3: Breakdown of response from Item 9 - 12

\begin{tabular}{|c|c|c|c|c|c|c|c|}
\hline $\mathbf{S} / \mathbf{N}$ & ITEM STATEMENT & \begin{tabular}{|l} 
SA \\
(4)
\end{tabular} & $\begin{array}{l}\mathbf{A} \\
\text { (3) }\end{array}$ & $\begin{array}{l}\text { SD } \\
\text { (2) }\end{array}$ & $\begin{array}{l}\text { D } \\
\text { (1) }\end{array}$ & TOTAL & $\mathbf{X W}$ \\
\hline 9. & $\begin{array}{l}\text { Increased workers productivity } \\
\text { Weight of response }\end{array}$ & $\begin{array}{l}20 \\
(80)\end{array}$ & (54) & (6) & (2) & $\begin{array}{l}43 \\
142\end{array}$ & 3.3 \\
\hline 10. & $\begin{array}{l}\text { Better relationship between workers are } \\
\text { management } \\
\text { Weight of response }\end{array}$ & $\begin{array}{l}19 \\
(76)\end{array}$ & $\begin{array}{l}19 \\
(57)\end{array}$ & $(4)$ & $\begin{array}{l}3 \\
(3)\end{array}$ & $\begin{array}{l}43 \\
140\end{array}$ & 3.2 \\
\hline 11. & $\begin{array}{l}\text { Work targets are met } \\
\text { Weight of response }\end{array}$ & $\begin{array}{l}18 \\
(72)\end{array}$ & $\begin{array}{l}19 \\
(57)\end{array}$ & $\begin{array}{l}3 \\
(6)\end{array}$ & $\begin{array}{l}3 \\
(3)\end{array}$ & $\begin{array}{l}43 \\
138 \\
\end{array}$ & 3.2 \\
\hline 12. & $\begin{array}{l}\text { Workers are always interested in their job. } \\
\text { Weight of response }\end{array}$ & $\begin{array}{l}19 \\
(76) \\
\end{array}$ & $\begin{array}{l}20 \\
(60)\end{array}$ & $(4)$ & (2) & $\begin{array}{l}43 \\
142\end{array}$ & 3.3 \\
\hline
\end{tabular}

\section{Source: Field Survey 2020}

\section{DECISION RULE}

We accept if mean of weighted mean is greater than $(>)$ criterion mean and reject if criterion mean is greater than $(>)$ mean of weighted means. Criterion mean $(\mathrm{x})=2.5$, mean $(\mathrm{x})$ of weighted means $=3.2$

Since the mean $\mathrm{x}$ of the weighted mean 3.2 is greater than $(>)$ the criterion mean 2.5 , the response from the respondents is positive. This means that, the items statements above in table 2.3 are the benefits of staff motivation in Bayelsa State Polytechnic Aleibiri.

\section{FINDINGS}

The findings from the study revealed that a lot of factors contribute to poor workers performance. Among such factors are non-implementation of staff promotion, non-payment of staff promotion arrears, lack of training programme to help workers acquire skill for better job performance, unconducive work environment among others. The above findings is line with Onitiri(1983) cited in Alamieyeseigha (2002: 115), that low staff productivity is an aspect of the vicious cycle of poverty in which many developing nations are trapped. He added that poor standard of living - bad health, lack of education, bad housing, poor transportation, bad conditions in the work place etc, reduced the workers' productivity and low productivity in turn reduces the capacity of the society to improve living standards.The findings also revealed that implementation of staff promotion and payment of promotion arrears, regular staff training 
programme to help them acquire the needed skill that will enhance their job performance and conducive work environment are factors that motivate and enhance workers performance. The findings are in tandem with Duku (1984: 22) assertion that the average Nigerian worker is motivated to work because of the monetary reward that accompanies work.

The benefits of staff motivation from the findings are, increasein workers' productivity, better relationship between management and workers among others. The findingsare in line with (Ojo and Sokoh, 2015:156) affirmation that, when worker are motivated, they become interested in their work, punctual to work, obedient to organizational rules and production targets are met or even surpassed.

\section{CONCLUSION}

Workers performance in any organization depends on the level of motivation given to them. It is therefore important that employees should be motivated so as to improve their performance effectively according to the expectations of the organization.

The knowledge of the needs of the workers will also help the manager in determining how to motivate them. The worker in an organization expects to get satisfaction for all his needs depending on the importance attached to such needs. His behaviour at work is also affected by these needs and so whatever needs a worker expects to satisfy becomes his/her goal that will influence the employee's work. Motivation helps to make the individual develop and intensify his/her desire to work effectively and efficiently for the overall benefit of the organization. It is therefore necessary to study the needs and emotions of an employeein order to motivate accordingly.

\section{RECOMMENDATIONS}

Based on the findings of the study, the researcher recommends the followings:

(i) That government should implement staff promotion and as well pay all outstanding promotion arrears to workers.

(ii) That every category of staff should be allowed to go on study leave with full pay to enable them acquire knowledge academically.

(iii) Workshops and seminars should be organized periodically to help workers acquire new skill that will enhance their performance. Government should endeavour to sponsor workers to attend conferences organized internationally and locally by reputable professional bodies as a way of updating workers' knowledge.

(iv) Management should provide conducive working environment for workers.

(v) Government and management should make as matter of policy to reward or award deserving workers who have rendered selfless service on yearly basis. This will further motivate the workers to put their best in the organization for maximum productivity. 


\section{REFERENCES}

Alamieyeseigha, D.S.P (2002). Managing employee productivity in Nigeria: A strategic approach, London: New African (UK) Limited.mn

Duku (1984). 'The Nigerian worker and output level'. Business Concord, June 8.

Faisal N. Al-M, Husam A, Faiz S and Dia Z (2017). The impact of employee motivation on organizational commitment. European Journal of Business and Management, (9) 15.

Mohsan, F., Nawaz, M. M., Khan, M., Shaukat, Z., and Aslam, N. (2004), Are employee motivation, commitment and job involvement inter-related: Evidence from banking sector of Pakistan. International Journal of Business and Social Science, (2) 17.

Mukoro, A. (2007). Human resources training and development for the civil service in Nigeria: A Delta State perspective. Charlotte, NC USA, Cataway Publishing Company.

Nwachukwu, C.C. (1988). Management theory and practice. Onitsha: African-Feb Publishers.

Obiajulu, S.O and Obi, E.A. (2004). Public administration in Nigeria: A developmental approach, Onitsha: Bookpoint Ltd.

Ojo J. and Sokoh C (2015). Essentials of public administration in Nigeria. Benin: Justice JecoPrinting and Publishing Global.

Onah F.O (2015). Human resources management. Enugu: University of Nigeria Press Ltd.

Sapru R.K (2013). Administrative theory and management thought ( $3^{\text {rd }} e d$ ). New Delhi: PHI Learning Private Limited.

Sohrab, A and Khurram, S. (2011). HRM and employee performance: a case of University teachers of Azard Jammu and Kashmir (AJK) in Paskistan. African Journal of Business Management, 5 (13).

Sharma M.P, Sadana B.L and Harpreet K. (2013). Public administration in theory and practice. New Delhi: Kitab Mahal Publishers.

Yaaya, A.D and Akinyele C.I (1992). New trends in personnel management.Ibadan: Spectrum Books Limited.

Zuheir, M.D (2018). Determinant of employee performance in Jordian organizations. Journal of Economics, Finance and Accounting, 5 (1). 